Karaman, G. (2020): Biodiversity of subterranean waters: redescription of poorly known Niphargus julius Stoch 1997 (Crustacea: Amphipoda: Niphargidae) from Italy (Contribution to the knowledge of the Amphipoda 314). Agriculture and Forestry, 66 (4): 239-258.

DOI: 10.17707/AgricultForest.66.4.19

\author{
Gordan S. KARAMAN ${ }^{1}$
}

\title{
BIODIVERSITY OF SUBTERRANEAN WATERS: REDESCRIPTION OF POORLY KNOWN NIPHARGUS JULIUS STOCH 1997 (CRUSTACEA: AMPHIPODA: NIPHARGIDAE) FROM ITALY (CONTRIBUTION TO THE KNOWLEDGE OF THE AMPHIPODA 314)
}

\begin{abstract}
SUMMARY
The subterranean species Niphargus julius Stoch 1997 (Crustacea: Amphipoda: Niphargidae), known from Prealpi Giulie (Friuli-Venetia Giulia region in Italy), described by Stanko Karaman (1954) as Niphargus stygius danconae, ssp. n. from cave "Grotta near Villanuova", was later renamed as Niphargus julius, new name, by F. Stoch (1997), because name "danconae" was already used for another species, Niphargus danconai Benedetti 1942 described from Verona (Italy). Nipharus julius was collected in various subterranean waters, mainly caves of Prealpi Giulie region, but after the short original description of this taxon of S. Karaman (1954), this species was never described and figured more in detail. This species is here described and figured based of material from type-locality. The some relations of this species regarding other similar species from NE Italy are discussed.
\end{abstract}

Keywords: taxonomy, redescription, Niphargus julius, Amphipoda, Niphargidae, Italy

\section{INTRODUCTION}

The subterranean waters of Europe, including Italy, are with very rich subterranean fauna only partially known and discovered. As these waters are today under pressure of overexploitation, pollution and other anthropogenic activity, the subterranean fauna existing in these waters, including Amphipoda, is in danger to be partially or completely destroyed before its discovery and investigation. As the fauna of Amphipoda in the subterranean waters of Italy is very rich and highly endemic, one detailed research of these animals seems to be very urgent.

In the previous period, when remarkably less number of species of Niphargus have been known, a much smaller number of taxonomical characters were used in description of new species, descriptions were relatively short and

\footnotetext{
${ }^{1}$ Gordan S. Karaman (corresponding author: karaman@t-com.me), Montenegrin Academy of Sciences and Arts, Podgorica, MONTENEGRO

Paper presented at the GEA (Geo Eco-Eco Agro) International Conference 2020, Podgorica.

Notes: The author declares that has no conflicts of interest. Authorship Form signed online.

Recieved:18/11/2020

Accepted:08/12/2020
} 
poorly figured. Along with the increase in the number of discovered species of Niphargus, there is an urgent need for more detailed description and figures of each species to facilitate the delimitation among similar taxa. For this reason we selected the subterranean species Niphargus julius Stoch 1997 (Crustacea: Amphipoda: Niphargidae), only partially known from Friuli-Venetia Giulia region in Italy, to redescribe it and draw more in detail, and by this way to make easier recognition of this species regarding several other similar species of $\mathrm{N}$. Italy and Slovenia.

This species was described as Niphargus stygius danconae, ssp. n., by Stanko Karaman (1954) from caves near Villanuova, but this name was nom. preocc. Name "danconae" was already used for another species, Niphargus danconai Benedetti 1942 described from Verona (Italy). Stoch (1997) put a new name for it, Niphargus julius, new nom., without any additional description of this taxon.

\section{MATERIAL AND METHODS}

The studied material was preserved in the $70 \%$ ethanol. The specimens were dissected using a WILD M20 microscope and drawn using camera lucida attachment. All body-parts were temporarily submersed in the mixture of glycerin and water for study and drawing. The body-length of examined specimens were measured by tracing individual's mid-trunk lengths (from tip of head to end of telson) using camera lucida. All illustrations were inked manually.

After study, all appendages were transferred to Liquid of Faure on permanent slides. The advantage of use of Liquid of Faure is that it is possible to remove again all dissected body-parts from Liquid of Faure by water and study it again from various positions under the microscope. After the study, these bodyparts can be put on slides in Liquid of Faure again and covered by thin cover glass making definitive microscopic slides.

Some morphological terminology and setal formulae follow G. Karaman's terminology (Karaman, G., 1969; 2012) regarding the distal mandibular palpus article $[\mathrm{A}=\mathrm{A}$-setae on outer face; $\mathrm{B}=\mathrm{B}$-setae on inner face; $\mathrm{C}=$ additional setae on outer face; $\mathrm{D}=$ lateral marginal $\mathrm{D}$-setae; $\mathrm{E}=$ distal long $\mathrm{E}$-setae], and propodus of gnathopods 1 and 2 [ $\mathrm{S}=$ corner $\mathrm{S}$-spine; $\mathrm{L}=$ lateral slender serrate $\mathrm{L}$ spines; $\mathrm{M}=$ facial corner $\mathrm{M}$-setae; $\mathrm{R}=$ subcorner $\mathrm{R}$-spine on inner face]. Terms "setae" and "spines" are used based on its shape, not origin.

Our studies are based on the morphological, ecological and zoogeographical investigations.

\section{TAXONOMICAL PART \\ Family NIPHARGIDAE \\ NIPHARGUS JULIUS STOCH 1997}

Figures 1-7

Niphargus (Stygoniphargus) stygius D' Anconae n. ssp., S. Karaman, 1954: 164, figs. 9-11; 
Niphargus stygius danconai G. Karaman \& Ruffo, 1986: 532; Stoch, 1993: 180; Stoch, 1996: 85.

Niphargus stygius G. Karaman, 1986: 215;

Niphargus stygius (part.) G. Karaman, 1993: 263;

Niphargus julius, n. nov., Stoch, F., 1997: 96, 98., Stoch, F. 2008: 110, 1 photo.

\section{MATERIAL EXAMINED: ITALY:}

$-346=$ Puint de Pratis, Friuli, Italy, 28.4.1929, one exp. (leg. Strasser) and one slide;

$-347=$ cave near Villanuova, Friuli, Italy, 12.8.1928, 2 exp. (leg. Strasser) and slide of holotypus;

S-6193= Grotta Nuova di Villanova Cave, Tarcento, NE Italy, 11. 11.1949, 4 exp. (leg. Busolini).

\section{DIAGNOSIS}

Metasomal articles with 8-10 dorsoposterior marginal short setae each. Epimeral plate 3 angular in males and females. Urosomal segment 1 at both dorsolateral sides with one seta in male and female, urosomal segment 2 with 2 spines. Mandibular palpus article 3 with elevated number of A and B-setae. Maxilla 1 inner plate with 2 setae, outer plate with 7 spines (6 spines with one lateral tooth only). Maxilliped inner plate with 3-4 distal spines, palpus with 2-3 setae at inner margin near basis of the nail. Coxae relatively short, coxa 4 unlobed posteriorly. Propodus of gnathopods 1-2 trapezoid, with inclined palm and elevated number of transverse rows of setae at posterior margin of propodus; Basipodit (article 2) of pereopods 5-7 dilated but without ventroposterior lobe; peduncle of pleopods 1-3 scarcely setose and with 2 retinacula each.

Uropod 1 peduncle with dorsointernal row of setae (except distal spine) and dorsoexternal row of spines, inner ramus only poorly longer than outer one in males and females. Uropod 3 long in males and females, but distal article of outer ramus shorter in females; telson strongly spinose, nearly as long as broad or poorly broader than long, provided with group of distal and facial spines, as well as with single lateral spines.

\section{DESCRIPTION. [S-6193, Cave Nuova di Villanova]:}

MALE $17.1 \mathrm{~mm}$ : Body strong, mesosomal segments dorsally smooth, metasomal segments 1-3 with 8-10 short dorsoposterior marginal setae (fig. 1G). Urosomal segment 1 with one dorsolateral seta on each side; urosomal segment 2 on each dorsolateral side with 2 spines and 2 setae, urosomal segment 3 naked (fig. 3A). Urosomal segment 1 with one weak spine at ventroposterior corner near basis of uropod 1-peduncle (fig. 3A).

Epimeral plate 1 with poorly marked ventroposterior corner and convex posterior margin provided with up to 8 short setae (fig. 1G), ventral margin slightly concave in the middle. 


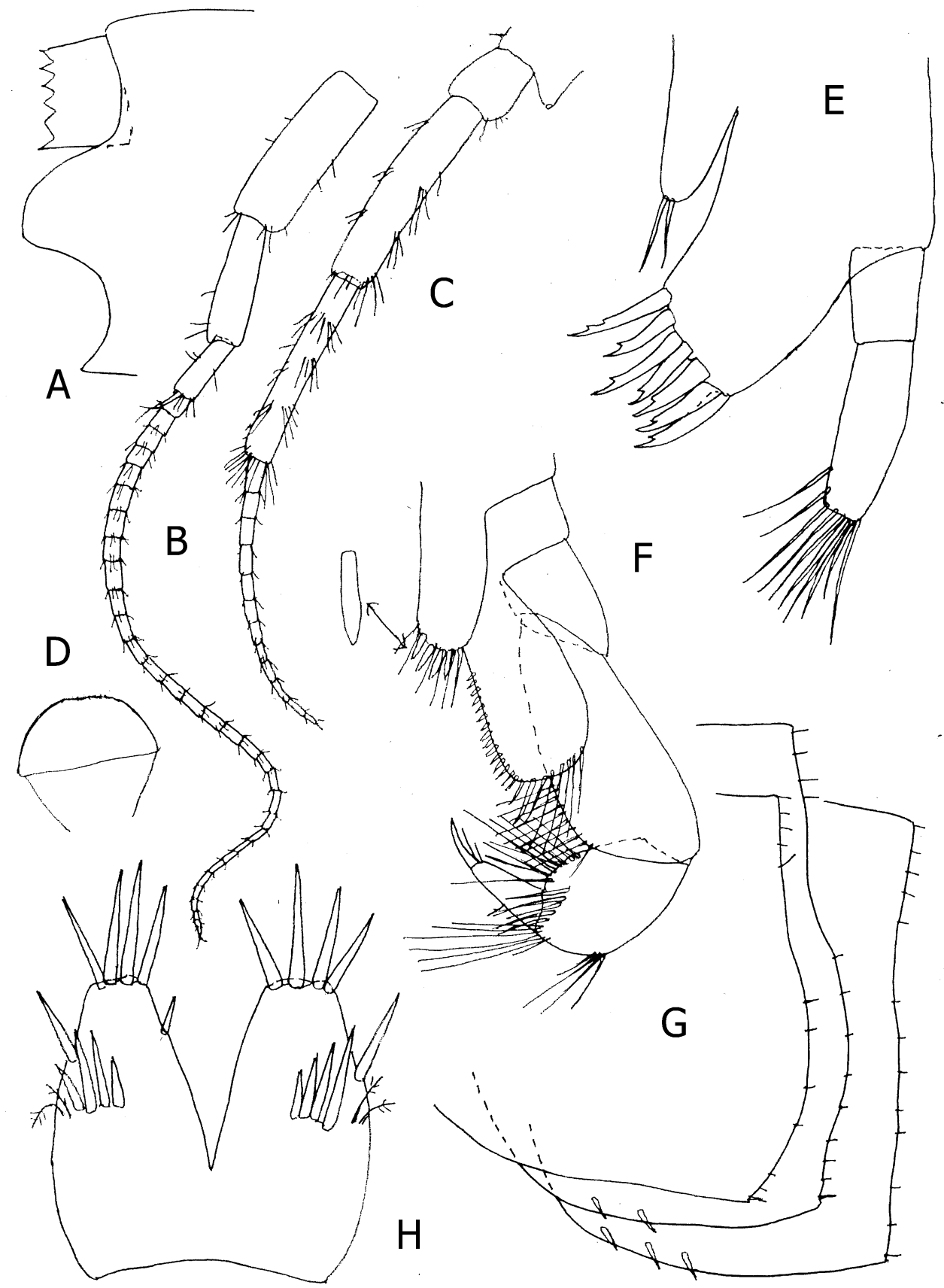

Fig. 1. Niphargus julius Stoch, 1997, Grotta Nuova di Villanova Cave, Male 17.1 $\mathrm{mm}: \mathrm{A}=$ head; $\mathrm{B}=$ antenna $1 ; \mathrm{C}=$ antenna $2 ; \mathrm{D}=$ labrum; $\mathrm{E}=$ maxilla $1 ; \mathrm{F}=$ maxilliped; $\mathrm{G}=$ epimeral plates $1-3 ; \mathrm{H}=$ telson. 

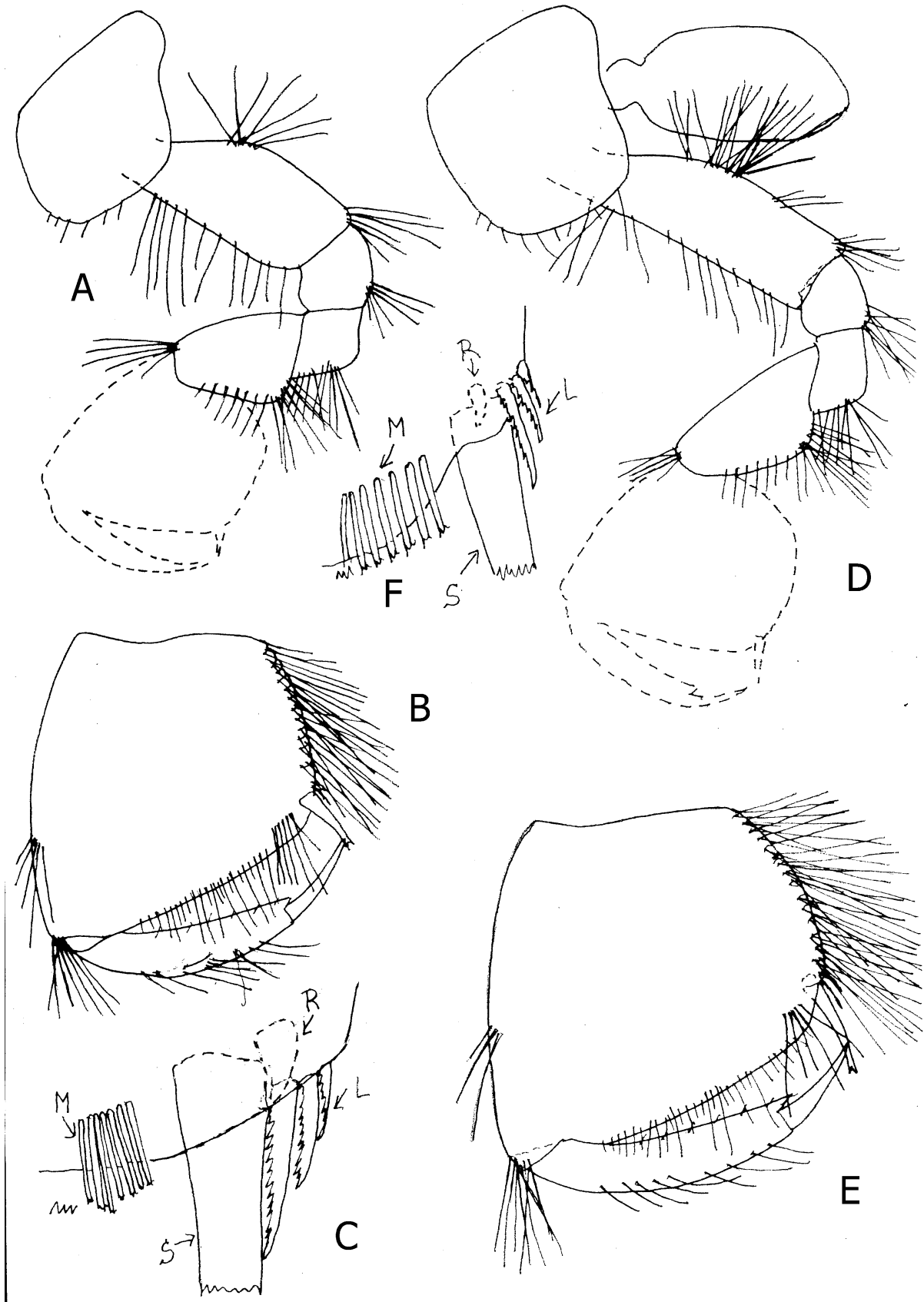

Fig. 2. Niphargus julius Stoch, 1997, Grotta Nuova di Villanova Cave, Male 17.1 $\mathrm{mm}$ : $\mathrm{A}-\mathrm{B}=$ gnathopod 1 , outer face; $\mathrm{C}=$ distal corner of gnathopod 1 propodus [S= corner spine; $\mathrm{L}=$ lateral spines; $\mathrm{R}=$ subcorner spine; $\mathrm{M}=$ facial $\mathrm{M}$-setae $]$; $\mathrm{D}$ $\mathrm{E}=$ gnathopod 2 , outer face; $\mathrm{F}=$ distal corner of gnathopod 2 propodus $[\mathrm{S}=$ corner spine; $\mathrm{L}=$ lateral spines; $\mathrm{R}=$ subcorner spine; $\mathrm{M}=$ facial $\mathrm{M}$-setae]; 
Epimeral plate 2 angular, with marked ventroposterior corner and slightly sinusoid posterior margin bearing nearly 9 short setae, ventral margin convex, bearing 2 submarginal spines.

Epimeral plate 3 distinctly angular, with nearly vertical posterior margin bearing nearly 8 short setae; ventral margin convex, with 3 submarginal spines. Ventroposterior corner of all three epimeral plates with stronger corner seta (not spine) (fig. 1G).

Head with short rostrum and well developed subrounded lateral cephalic lobes, ventroanterior sinus deep (fig. 1A), eyes absent.

Antenna 1 reaching nearly half of body, peduncular articles 1-3 progressively shorter (ratio: 49:35:19), scarcely setose (fig. 2); main flagellum consisting of 32 articles (some of them with one aesthetasc); accessory flagellum short, 2-articulated, reaching nearly half of last peduncular article (fig. 1B).

Antenna 2 relatively slender; peduncular article 4 slightly longer than article 5 (ratio: 59:55), both articles bearing several bunches of short setae, mostly shorter than diameter of article itself (fig. 3); flagellum slender, longer than last peduncular article and consisting of 12 articles; conus excretorius short (fig. 1C).

Mouthparts well developed. Labrum broader than long, with entire distal margin (fig. 1D). Labium broader than long, inner lobes well developed, outer lobes entire (fig. 5A).

Mandibles with triturative molar. Left mandible: incisor with 5 teeth, lacinia mobilis with 4 strong teeth, and 6 rakers. Right mandible: incisor with 4 teeth, lacinia mobilis bifurcate, with several teeth, and 7 rakers. Palpus 3articulate: first article naked, second article with 16 setae; third article subfalciform, rather longer than article 2 (ratio: 75:67), provided with nearly 5-6 E-setae, 32 D-setae, on outer face with 2 groups of A-setae (10+2) (fig. 3B), on inner face with 4 groups of setae (5-4-4-2) (fig. 3C).

Maxilla 1: inner plate short, with 2 setae; outer plate with 7 distal spines (6 spines with one lateral tooth, one spine with 2 lateral teeth); palpus 2-articulate, distal article not reaching distal tip of spines and provided with 10 setae (fig. 1E).

Maxilla 2: both plates longer than broad, inner plate rather smaller than outer one, both with distomarginal setae only (fig. 3D).

Maxilliped: left inner plate with 4 distal spines mixed with several setae; right inner plate with 3 distal spines mixed with several setae; outer plate reaching up to half of second palpus article and provided with nearly 15-16 marginal pointed spines and distal setae (fig. 1F); palpus 4-articulated, article 3 along outer margin with one median and one distal group of setae; article 4 at outer margin with one median seta, along inner margin with 2 setae near basis of the nail (fig. 1F).

Coxae 1-4 moderately short. Coxa 1 broader than long (ratio: 50:38), with subrounded ventroanterior corner and provided with 6-7 marginal setae (fig. 2A).

Coxa 2 hardly longer than broad (ratio: 53:51, ventral margin subrounded and provided with nearly 9 marginal setae (fig. 2D). 


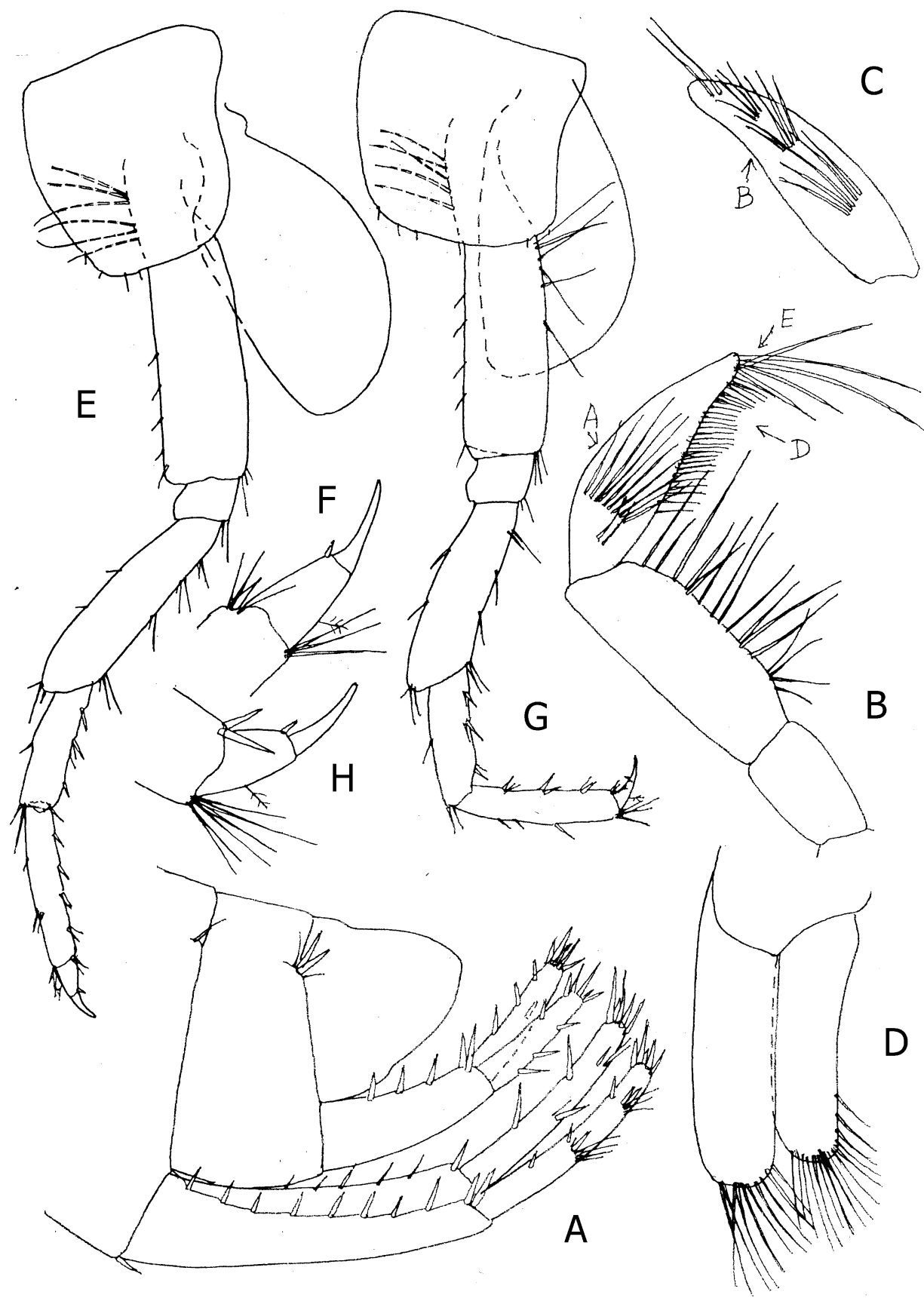

Fig. 3. Niphargus julius Stoch, 1997, Grotta Nuova di Villanova Cave, Male 17.1 $\mathrm{mm}: \mathrm{A}=$ urosome with uropods $1-2 ; \mathrm{B}=$ mandibular palpus, outer face $[\mathrm{A}=\mathrm{A}$ setae; $\mathrm{D}=\mathrm{D}$-setae; $\mathrm{E}=\mathrm{E}$-setae]; $\mathrm{C}=$ distal palpus article, inner face $[\mathrm{B}=\mathrm{B}$-setae $]$. $\mathrm{D}=$ maxilla $2 ; \mathrm{E}-\mathrm{F}=$ pereopod $3 ; \mathrm{G}-\mathrm{H}=$ pereopod 4 . 


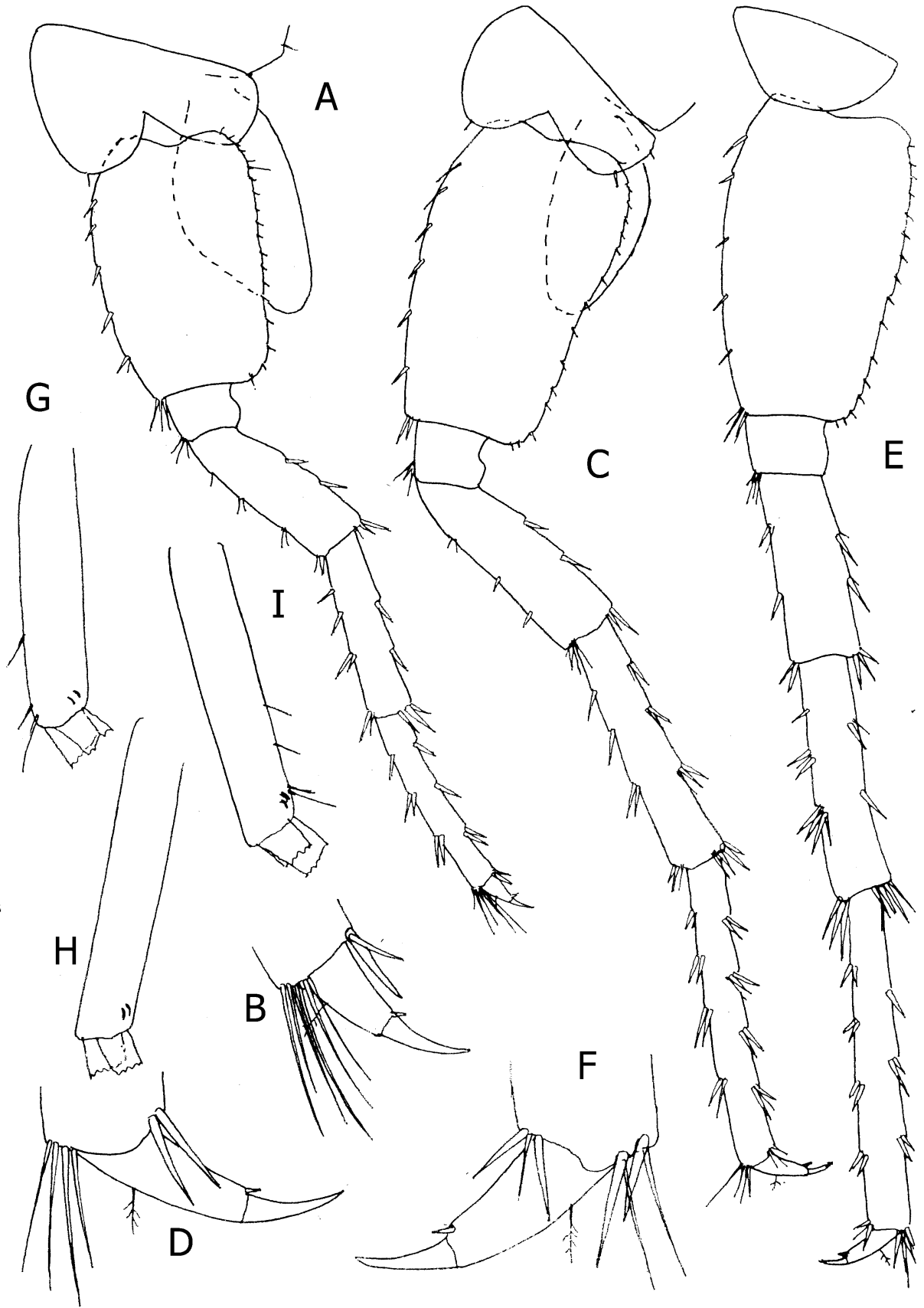

Fig. 4. Niphargus julius Stoch, 1997, Grotta Nuova di Villanova Cave, Male 17.1 $\mathrm{mm}: \mathrm{A}-\mathrm{B}=$ pereopod $5 ; \mathrm{C}-\mathrm{D}=$ pereopod $6 ; \mathrm{E}-\mathrm{F}=$ pereopod $7 ; \mathrm{G}=$ pleopod 1 peduncle; $\mathrm{H}=$ pleopod $2=$ peduncle; $\mathrm{I}=$ pleopod 3 peduncle. 
Coxa 3 only slightly longer than broad (ratio: 58:55) with nearly 5 marginal setae (fig. 3E). Coxa 4 slightly broader than long (ratio: 59:55), with nearly 6 marginal setae, ventroposterior lobe not developed (fig. 3G).

Coxae 5-7 relatively short. Coxa 5 bilobed, much broader than long (ratio: 63:37), anterior lobe broadly subrounded, with single marginal setae (fig. 4A). Coxa 6 smaller than coxa 5, bilobed, broader than long (ratio: 53:33) (fig. 4C). Coxa 7 short, entire, broader than long (ratio: 44:22) (fig. 4E).

Gnathopods 1-2 moderately large, with propodus not distinctly larger than corresponding coxae (fig. 2A, D). Gnathopod 1: article 2 along anterior margin with row of long single setae, along posterior margin with several bunches of long setae often extending diameter of article itself. Article 3 at posterior margin with one distal bunch of setae (fig. 2A); article 5 nearly as long as propodus, along anterior margin with distal bunch of setae, along posterior margin with numerous setae. Propodus trapezoid (Fig. 2B), slightly longer than broad (ratio: $83: 74$ ), along posterior margin with 12 transverse rows of setae; palm inclined nearly half of propodus-length, defined on outer face by corner S-spine accompanied laterally by 2-3 L-spines and facial 5- 7 M-setae (fig. 2C), on inner face by one subcorner R-spine. Dactylus reaching posterior margin of propodus, along outer margin with 11 setae [1-1-1-1-1-3-2-1) or: 1-1-2-3-2-1-1)]; along inner margin are present several short single setae (fig. 2B).

Gnathopod 2: article 2 along anterior margin with row of long single setae, along posterior margin with bunches of long setae (setae are shorter towards distal part of article); article 3 with bunch of longer setae at distoposterior margin (fig. 2D); article 5 almost as long as propodus, along anterior margin with distal bunch of setae, along posterior margin with numerous setae. Propodus trapezoid, rather larger than that of gnathopod 1, hardly longer than broad (ratio: 90:87), along posterior margin with 15 transverse rows of setae; palm inclined nearly half of propodus-length, convex, defined on outer face by corner S-spine accompanied laterally by $2-3$ serrate L- spines sitting laterally very close to S-spine, and by 5-7 facial M-setae, on inner face by one subcorner R-spine (fig. 2F). Dactylus reaching posterior margin of propodus, along outer margin with row of 9 single setae, or row of 10 setae (1-1-1-2-3-2); along inner margin appear several short single setae (fig. 2E).

Pereopods 3-4 moderately strong. Pereopod 3: article 2 in proximal part with long anterior and posterior setae, in distal part setae are short and less numerous; articles 4-6 of different length (ratio: 55:33:43), article 4 along both margins with single or groups of short setae; article 5 along posterior margin with single short spines; article 6 along posterior margin with 5 single slender spines (fig. 3E). Dactylus short and strong, much shorter than article 6 (ratio: 16:43), along inner margin with one strong spine near basis of the nail, along outer margin with one median plumose seta; nail nearly as long as pedestal (fig. 3F).

Pereopod 4 similar to pereopod 3, but hardly shorter; pilosity of article 2 like that of pereopod 3; articles 4-6 of different length (ratio: 51:32:41); article 4 along posterior margin with 4 setae and one spine, along anterior margin with 2 
median and 3 distal setae; article 5 along posterior margin with 3 single or pair of short spines, along anterior margin with one median and 2-3 distal setae; article 6 along posterior margin with 4 single or pairs of short spines (fig. 3G). Dactylus short and strong, much shorter than article 6 (ratio: 17:41), along outer margin with one median plumose seta, along inner margin with one strong spine near basis of the nail (fig. 3H); nail is hardly shorter than pedestal.(ratio 27:30).

Pereopods 5-7 moderately stout, pereopod 5 distinctly shorter than pereopods 6 and 7. Pereopod 5: article 2 dilated, longer than broad (ratio: 69:43), anterior convex margin provided with row of nearly 6 single or pairs of spine-like setae, along posterior almost straight margin with nearly 18 short setae, ventroposterior part dilated but not lobed (fig. 4A). Articles 4-6 of different length (ratio: 46:47:50), all articles along both margins with single or pairs of short spines; only article 4 along anterior margin with 3 median groups of short setae. Article 2 slightly longer than article 6 (ratio: 69:50). Dactylus much shorter than article 6 (ratio: 15:50), strong, at inner margin with one strong spine near basis of the nail, along outer margin with one median plumose seta (fig. 4B);-nail as long as pedestal.

Pereopod 6: article 2 much longer than broad (ratio: 81:49), anterior convex margin with row of 7 single slender spines; posterior margin slightly concave in the middle, along margin with nearly 16 short setae; ventroposterior dilatation without lobe (fig. 4C). Articles 4-6 of different length (ratio: 59:69:81), along both margins with single or bunches of short spines. Article 2 nearly as long as article 6. Dactylus much shorter than article 6 (ratio: 21:81), along inner margin with strong spine near basis of the nail, along outer margin with one median plumose seta (fig. 4D); nail shorter than pedestal (ratio: 28:50).

Pereopod 7 poorly shorter than pereopod 6; article 2 much longer than broad (ratio: 85:47), along anterior convex margin with row of 6 slender spines, along posterior poorly convex margin with 16 short setae, ventroposterior part of article 2 narrowed (fig. 4E). Articles 4-6 of different length (ratio: 50:63:88), along both margins with bunches of short spines (spines are shorter than diameter of articles themselves). Article 6 poorly longer than article 2 (ratio: 88:85). Dactylus much shorter than article 6 (ratio: 24:88), along inner margin with strong spine near basis of the nail, on outer margin with median plumose seta (fig. 4F); nail shorter than pedestal (ratio: 26:47).

Pleopods 1-3 with 2 retinacula each. Peduncle of pleopod 1 along anterior margin with 3 single setae (fig. 4G); peduncle of pleopod 2 naked (fig. $4 \mathrm{H}$ ); peduncle of pleopod 3 along posterior margin with 2 distal and 2 median setae (fig. 4 I).

Coxal gills ovoid, relatively short, not reaching ventral margin of corresponding article 2 (figs. 2D, 3E, G; 4A, C).

Uropods 1-2 rather stout. Uropod 1: peduncle with dorsointernal row of setae (except distal spine) and dorsoexternal row of spines (fig. 3A); rami shorter than peduncle: inner ramus with 2 single lateral spines at inner margin and 2 lateral spines at outer margin (both accompanied by bunch of 3-4 simple setae; 
outer ramus only slightly shorter than inner ramus, with 3 lateral spines at inner margin and 2 single spines at outer margin accompanied by 2-4 simple setae each; at tip of rami appear 5 distal short spines (fig. 3A).

Uropod 2: peduncle with row of dorsal spines; inner ramus only poorly longer than outer one, with 3 spines along outer margin and one spine at inner margin, at top with 5 distal short spines; outer ramus with 3 lateral and one median spine; at top are attached 5 distal short spines (fig. 3A).

Uropod 3 long; peduncle longer than broad, with 3-4 distal short spines; inner ramus much shorter than peduncle, bearing 2 distal spines and one plumose seta; outer ramus long, 2-articulated: first article along outer margin with 3 median spines and distal bunch of short spines, along inner (mesial) margin with 5 groups of single or pair of spines accompanied by single plumose setae not exceeding diameter of article itself; second article poorly shorter than first one (ratio: 125:135), along both margins and tip with single simple setae (fig. 5B).

Telson poorly broader than long, incised nearly $2 / 3$ of telson-length; each lobe with 4 distal long spines, one outer marginal spine and 4 median facial spines; left lobe with one mesial marginal spine (fig. 1H).

FEMALE $13.1 \mathrm{~mm}$ with 10 eggs in marsupium: Metasomal segments 13 with 8-10 dorsoposterior marginal setae (fig. 6F); urosomal segment 1 on each dorsolateral side with one seta; urosomal segment 2 on each dorsolateral side with 2 spines and 2 setae; urosomal segment 3 naked. Urosomal segment 1 at ventroposterior corner with one weak spine near basis of uropod 1-peduncle (fig. $7 \mathrm{E})$.

Epimeral plates 1-2 obtusely angular, epimeral plate 3 distinctly angular. Epimeral plate 1 with ventral margin slightly concave in the middle and convex posterior margin bearing nearly 10 setae, corner spine-like seta is weak. Epimeral plate 2 with convex ventral margin bearing one submarginal spine, posterior margin poorly convex, bearing nearly 10 setae, including corner weak spine-like seta. Epimeral plate 3 with convex ventral margin bearing 3 subventral spines, posterior margin nearly straight, inclined, bearing nearly 11 setae, including weak corner spine-like seta (fig. 6F).

Head and antennae mainly like these in males. Antenna 1 reaching nearly half of body, main flagellum with 28 articles. Antenna 2 rather more setiferous, peduncular articles 4-5 with longer setae, flagellum with 10 articles (fig. 5C).

Mouthparts mainly like these in male. Mandibles: right mandible incisor and lacinia mobilis like these in male, incisor with 4 teeth and serrate lacinia mobilis accompanied by 8 rakers (fig. 6A). Mandibular palpus article 2 with 20 setae; article 3 subfalciform, slightly longer than article 2, bearing $33 \mathrm{D}$-setae, 7 E-setae, 2 groups of A-setae (8-1) and 4 groups of B-setae (7-6-5-1).

Maxilla 1 inner and outer plate like these in male, palpus article 2 with 11 setae. 


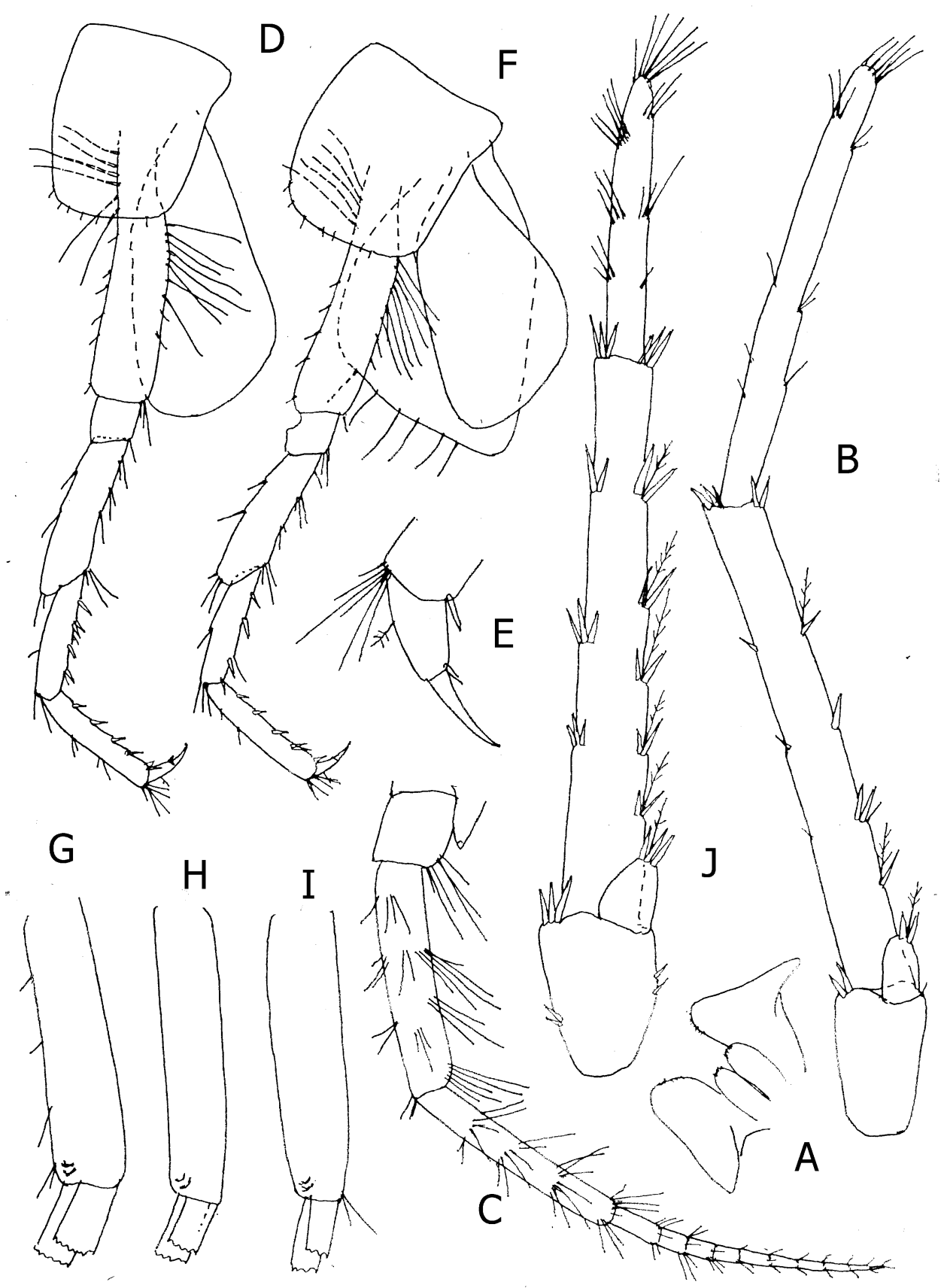

Fig. 5. Niphargus julius Stoch, 1997, Grotta Nuova di Villanova Cave, Male 17.1 mm: A= labium; $\mathrm{B}=$ uropod 3 .

Female $15.1 \mathrm{~mm}: \mathrm{C}=$ antenna $2 ; \mathrm{D}=$ pereopod $3 ; \mathrm{E}-\mathrm{F}=$ pereopod $4 ; \mathrm{G}=$ pleopod 3 peduncle; $\mathrm{H}=$ pleopod 2 peduncle; $\mathrm{I}=$ pleopod 3 peduncle. 


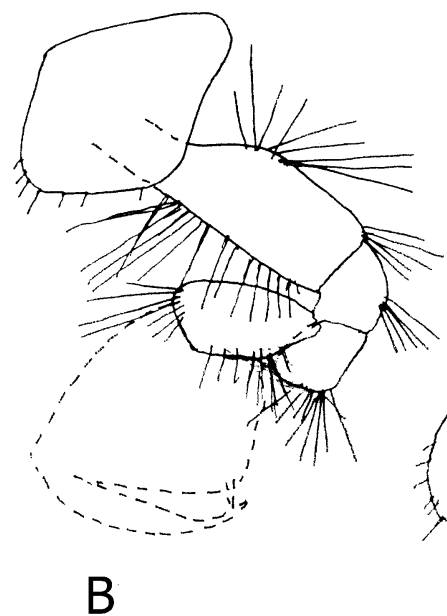

$\mathrm{B}$

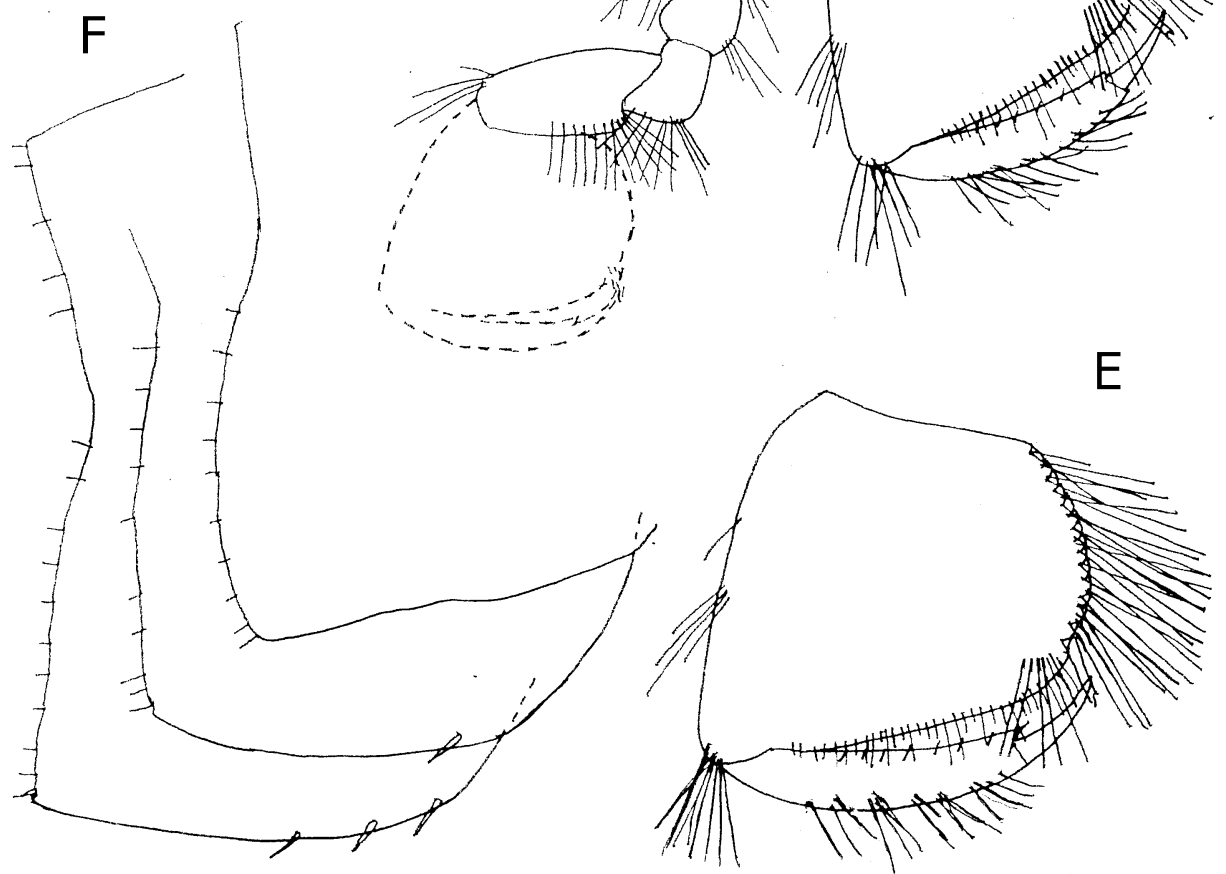

Fig. 6. Niphargus julius Stoch, 1997, Grotta Nuova di Villanova Cave, Female $15.1 \mathrm{~mm}: \mathrm{A}=$ right mandible, incisor and lacinia mobilis with rakers; $\mathrm{B}-\mathrm{C}=$ gnathopod 1; $\mathrm{D}-\mathrm{E}=$ gnathopod $2 ; \mathrm{F}=$ epimeral plates $1-3$. 
Maxilliped: inner plate of left maxilliped with 5 distal spines, that of right maxilliped with 4 distal spines; palpus article 4 with 2-3 setae at inner margin near basis of the nail.

Coxa 1 broader than long (ratio: 40:32) with subrounded ventroanterior part and 7 ventral marginal setae (fig. 6B); coxa 2 longer than broad (ratio: 46:40), ventral margin convex, provided with 11 setae (fig. 6D). Coxa 3 longer than broad (ratio: 52:43), at ventral margin with 7-8 setae (fig. 5D). Coxa 4 poorly longer than broad (ratio: 52:45), with nearly 8 marginal setae, ventroposterior dilatation absent (fig. $5 \mathrm{~F}$ ).

Coxae 5-7 short. Coxa 5 bilobed, much broader than long (ratio: 52:38), anterior lobe subrounded and not produced (fig. 7A). Coxa 6 smaller than 5, bilobed, broader than long (ratio: 42:30) (fig. 7B). Coxa 7 entire, much broader than long (ratio: 40:20) (fig. 7C).

Gnathopods 1-2 of the moderate size, with propodus nearly as large as corresponding coxa (fig. 6B, D). Gnathopod 1 moderately smaller than gnathopod 2; article 2 along anterior margin with row of long single setae, along posterior margin with proximal and distal bunch of setae and several setae in distal part of article; article 3 at posterior margin with distal bunch of setae; article 5 shorter than propodus (ratio: 29:40), along anterior margin with distal bunch of setae (fig. 6B), along posterior margin with numerous setae. Propodus trapezoid, slightly longer than broad (ratio: 67:60), along posterior margin with 14 transverse rows of setae (fig. 6C); palm slightly convex, inclined nearly half of propodus-length, defined on outer face by corner S-spine accompanied laterally by 3-4 serrate Lspines and 6-7 facial M-setae (fig. 6C), on inner face by one subcorner R-spine. Dactylus reaching posterior margin of propodus, along outer margin with nearly 13-14 single or paired setae (1-2-1-2-1-1-2-1-1-1), along inner margin with several short single setae.

Gnathopod 2: article 2 along anterior margin with row of numerous long setae, along posterior margin with proximal bunch of setae and several setae in distal part. Article 3 at posterior margin with distal bunch of setae (fig. 7D); article 5 slightly shorter than propodus (ratio: 37:40), along anterior margin with distal bunch of setae, along posterior margin with numerous setae. Propodus trapezoid, only slightly longer than broad (ratio: 75:70), along posterior margin with 14 transverse rows of setae; palm slightly convex, inclined nearly half of propodus-length, defined on outer face by corner S-spine accompanied laterally by $2 \mathrm{~L}$-spines and 6 facial M-setae, on inner face by one subcorner R-spine (fig. 7E). Dactylus reaching posterior margin of propodus, along outer margin with nearly 13-14 single or paired setae (1-2-3-2-2-2-1-1), along inner margin with row of short setae.

Pereopod 3 moderately strong; article 2 in proximal part with numerous long setae at both margins (fig. 5D) and short setae in distal part. Articles 4-6 of different length (ratio: 43:30:37); article 4 along both margins with single or pairs setae not exceeding diameter of article itself; article 5 along posterior margin with 4 single spines mixed with single short seta, along anterior margin with single 
setae; article 6 along posterior margin with 5 single spines sometimes with one short seta, along anterior margin with several short setae. Dactylus much shorter than article 6 (ratio: 21:37), along inner margin with one spine near basis of the nail, along outer margin with one median plumose seta; nail shorter than pedestal (ratio: 26:32) (fig. 5E).

Pereopod 4: article 2 in proximal part along both margins with row of long setae, and short setae in distal part; articles 4-6 of different length (ratio: 40:30:36); article 4 along both margins with short setae; article 5 along posterior margin with 3 groups of 1-2 spines and single setae; article 6 along posterior margin with row of 5 single spines mixed sometimes with single short seta (fig. 4F); dactylus much shorter than article 6 (ratio:16:36), along inner margin with one spine near basis of the nail, along outer margin with one median plumose seta; nail like that in pereopod 3 .

Pereopod 5 remarkably shorter than pereopods 6 and 7 (fig. 7A, B, C), article 2 much longer than broad (ratio: 58:32), with almost parallel lateral margins, along anterior slightly convex margin appear a row of 6 single spine-like setae and distal bunch of setae, posterior almost straight margin provided with nearly 15 short setae; ventroanterior part not produced, ventroposterior dilatation isn't lobed (fig. 7A). Articles 4-6 of different length (ratio: 44:49:51), all these articles along both margins with short spines, sometimes mixed with single short seta. Article 2 is longer than article 6 (ratio: 58:51). Dactylus much shorter than article 6 (ratio: 16:51), along inner margin with one spine near basis of the nail, along outer margin with one median plumose seta, nail shorter than pedestal.

Pereopod 6: article 2 much longer than broad (ratio: 72:39), weakly tapering ventrally, along anterior weakly convex margin appear a row of 8 short spine-like setae, along posterior almost straight margin are attached 13 short setae; ventroposterior dilatation not forming lobe (fig. 7B). Articles 4-6 of different length (ratio: 50:67:76), along both margins of these articles appear bunches of single or paired spines accompanied often with single short setae (fig. 7B). Article 2 is poorly shorter than article 6 (ratio: 72:76). Dactylus much shorter than article 6 (ratio: 27:76), along inner margin with one spine near basis of the nail, along outer margin with one median plumose seta, nail shorter than pedestal.

Pereopod 7 scarcely shorter than pereopod 6; article 2 much longer than broad (ratio: 75:41), along anterior slightly convex margin appear 7 single spinelike setae, along posterior slightly convex margin appear nearly 13 short setae, ventroposterior corner without lobe. Articles 4-6 of different length (ratio: 45:55:75), along both margins with short spines mixed sometimes with single short seta (fig. 7C). Article 2 nearly as long as article 6. Dactylus much shorter than article 6 (ratio: 27:75), along inner margin with spine near basis of the nail, along outer margin with one median plumose seta; nail shorter than pedestal (ratio: 27:50) (fig. 7D). 


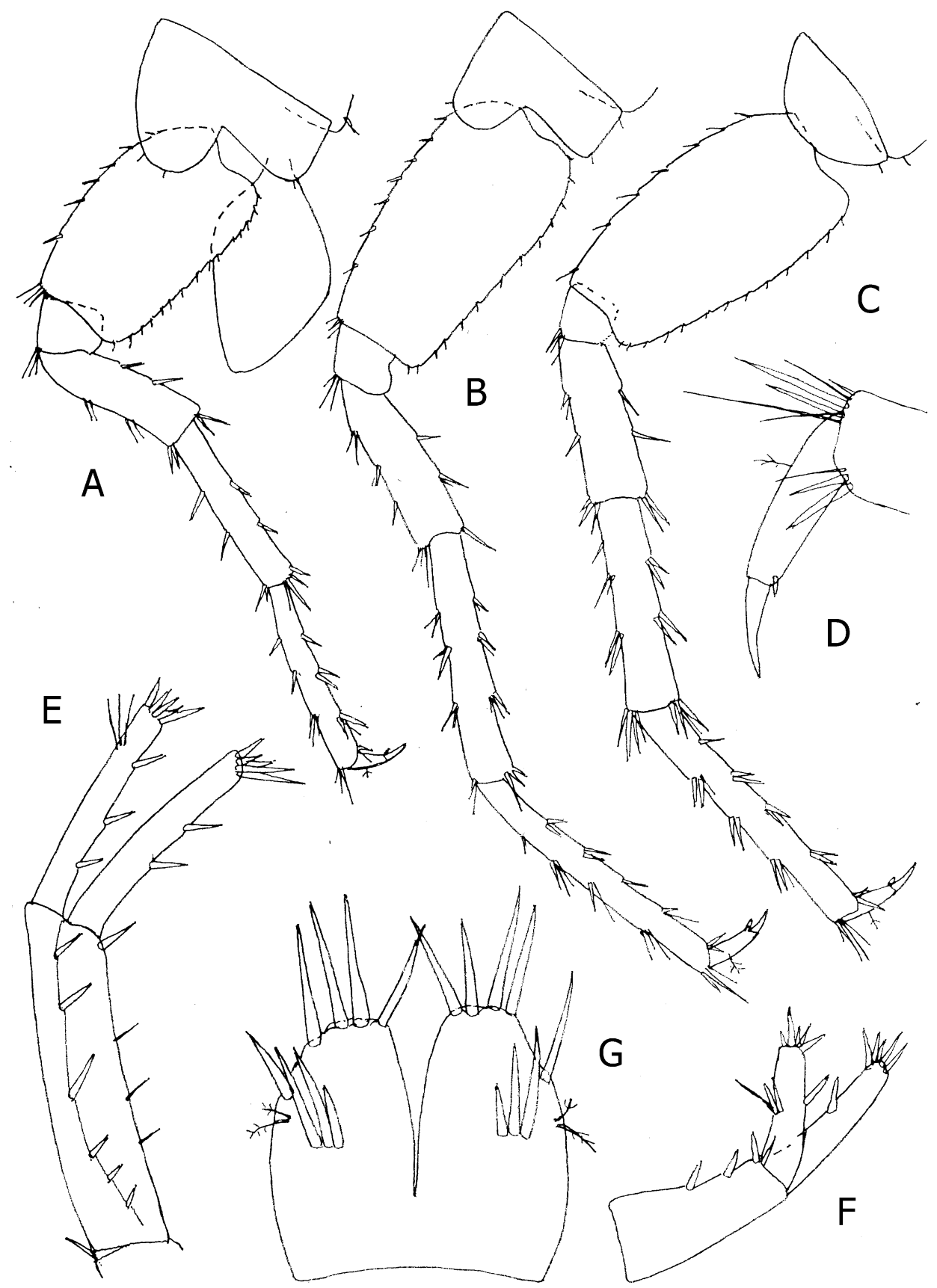

Fig. 7. Niphargus julius Stoch, 1997, Grotta Nuova di Villanova Cave, Female $15.1 \mathrm{~mm}: \mathrm{A}=$ pereopod $5 ; \mathrm{B}=$ pereopod $6 ; \mathrm{C}-\mathrm{D}=$ pereopod $7 ; \mathrm{E}=\operatorname{uropod} 1 ; \mathrm{F}=$ uropod 2; $\mathrm{G}=$ telson. 
Pleopods 1-3 with 2 retinacula. Peduncle of pleopod 1 with 2 distal simple setae (fig. $5 \mathrm{G}$ ); peduncle of pleopod 2 naked (fig. $5 \mathrm{H}$ ); peduncle of pleopod 3 with 4-5 short simple setae along posterior margin (fig. 5 I).

Uropods 1-2 stout. Uropod 1 rami shorter than peduncle. Peduncle with dorsointernal row of setae (except distal spine), and dorsoexternal row of spines (fig. 7E). Inner ramus only slightly longer than outer one, with 2-3 lateral and 5 distal short spines. Outer ramus with 3 lateral spines and one subdistal bunch of simple setae, at top appear 5 distal short spines.

Uropod 2: peduncle with 4 dorsal spines; inner ramus very poorly longer than outer one, with one lateral and 5 distal spines; outer ramus with 2 lateral spines and one simple seta at outer margin, and 2 single spines at mesial margin (fig. 7F); at top are attached 5 unequal spines.

Uropod 3 long, but shorter than that of male. Peduncle slightly longer than broad, with 2 lateral spines and setae and 3 distal spines; inner ramus scale-like, much shorter than peduncle (fig. 5J) and provided with 3 distal spines. Outer ramus 2-articulated: first article long, along outer margin with 4 bunches of short spines, along inner (mesial) margin with 6 bunches of spines mixed with single plumose setae longer than spines; distal article long but shorter than first one (ratio: 77:150), along both margin and tip with several bunches of simple setae (fig. 5J).

Telson only slightly broader than long, incised nearly $2 / 3$ of telson-length; each lobe with 4 distal and one outer marginal longer spine; a bunch of 3 median facial spines attached on each lobe; a pair of short plumose setae is attached in the middle of outer margin of each lobe (fig. 7G).

Coxal gills broad, but not exceeding ventral margin of corresponding article 2 (gnathopod 2, pereopods 3 and 4) (figs. 5D, F; 6D), or shorter (pereopods 5 and 6) (fig. 5A).

Oostegites very broad, with marginal setae (fig. 5F).

\section{VARIABILITY.}

Females rather similar to males, but with slightly longer anterior coxae. Metasomal segmens 1-3 with 8-10 dorsoposterior marginal setae.

Dactylus of all pereopods always with strong spine at inner margin near basis of the nail; Dactylus of gnathopods 1-2 along outer margin mainly with row of single setae, but often appear some groups of 2 setae, or rarely 3 setae. Antenna 2 in female slightly more setose than that in male. The males and females have similar shape of epimeral plates.

Stanko Karaman figured 3 different telsons showing the variability in number of spines and proportion of telsons: telson as long as broad, telson poorly longer than broad and telson poorly broader than long (S. Karaman, 1954, figs. 9$11)$.

The male $15.5 \mathrm{~mm}$ from Punt de Pratis: propodus of gnathopods 1 and 2 with corner S-spine accompanied laterally by $3 \mathrm{~L}$-spines; and 6-7 M-setae; setae along outer margin of dactylus in gnathopods 1-2 like these in holotype of 
Villanova. Maxilliped: inner plate with 3 and 4 distal spines, palpus article 4 at inner margin with 2 setae near basis of the nail.

\section{REMARKS AND AFFINITIES.}

Stanko Karaman (1954) underlines main differences of this species regarding N. stygius and some other similar populations of Niphargus stygiusComplex from N. Italy and Slovenia.

Based on present knowledge of this complex we can mentioned some of them regarding $N$. julius.

N. stygius stygius (Schiödte, 1847) [loc. typ.: Postojnska jama Cave, Slovenia] differs distinctly from $N$. julius by absence of facial spines on telson, by shorter distal article of uropod 3 outer ramus in female, maxilla 1, etc.

Niphargus valvasori S. Karaman 1952 [loc. typ.: Križna Jama Cave, Slovenia] differs from $N$. julius by different maxilla 1 , by absence of facial spines on telson, etc.

N. costozzae Schellenberg 1935 [loc. typ.: "Covolo della guerra" Cave, Lumignano, Monti Berici Mt., N. Italy, is also rather similar to $N$. julius, but differs by less spiniferous telson, elevated number of setae on maxilla 1 inner plate, presence of spine on urosomal segment 1, etc.

From northern Italy have been described several other similar species [ $N$. dolenianensis Lorenzi 1898 [loc. typ. Dolegnano, between Udine and Gorizia], $N$. lessiniensis Stoch 1998 (loc. typ.: Lessinian Mts, Verona), N. stebbingi Cecchini 1928 [loc. typ.: Poggio degli Balzi, Toscana], N. tridentinus Stoch 1998 (loc. typ.: Grotta delIa Bigonda" Cave, Grigno, Trento), N. montellianus Stoch 1998 [loc. typ.: Massif of Montello, Venetia] etc., but these species differs from $N$. julius by various characters, although some of them are very scarcely described and needs verification and detailed description. As the entire Niphargus stygius-Complex from northern Italy is still in the process of study, we have given up here further comparison with other taxa of this group. Probably the new molecular genetics study of all these taxa will put more light on the problem of delimitation of all these taxa.

LOCUS TYPICUS: Grotta Nuova di Villanova Cave, Fr 323, N. Italy.

\section{LOCALITIES CITED:}

S. Karaman (1954) cited this species for Cave Villanuova and Puint de Pratis. Stoch (2008) mentioned this species in numerous localities as author (several papers) or as coauthor with S. Ruffo (2005), Dorigo (2007) and Colla (2002): Buse da l'Ors-Cave (Fr 64), Grotta del Cret dal Landri-Cave (Fr 58), Grotta di Monteprato-Cave (Fr 59), Grotta di Taipana-Cave (Fr 61), Grotta Furmie-Cave (Fr 187), cave of quarry in Papipano (Fr 296), Grotta Pod LanisceCave (Fr 573), Grotta di Canebola-Cave (Fr 1080), Grotta Doviza-Cave (Fr 70), Grotta Egidio Feruglio-Cave ( Fr 2175), Grotta Nuova di Villanova-Cave ( $\mathrm{Fr}$ 323), Grotta Pre Oreak-Cave (Fr 65), spring "sul sentiero 727” (Fr 2786); springs 
of Torlano water system; springs on left bank of torrent Vedronza in the valley of Casera Morandin.

DISTRIBUTION: Niphargus julius is endemic species of NE part of Italy (Prealpi Giulie, Venezia Giulia).

\section{REFERENCES}

BENEDETTI, G.B. 1942. Prime osservazioni sopra i Niphargus della Venezia Euganea. - Memorie R. Accad. Sc. Let. Arti Padova (n. s.), 58: 175-186.

CECCHINI, C. 1928. Contributo alla conoscenza degli Anfipodi. - Reale Comitato Talassografico Italiano; Istituto di Zoologia, Anatomia e Fisiologia comparata della R. Universita di Siena, Memoria, 142: 1-10, 2 pls., Venezia.

COLLA, A. \& STOCH, F. 2002. Prime ricerche biospeleologiche nelle grotte dei Monti Musi (Parco Naturale delle Prealpi Giulie).- Atti del Museo civico di Storia naturale, Trieste, 49: 93-112.

DORIGO, L. \& STOCH, F. 1997. La fauna sotterranea. In: Il sistema sotterraneo Vigant - Pre Oreak (Nimis, Udine, Prealpi Giulie). Arti Grafiche Friulane, Udine: 80-89.

KARAMAN, G. 1969. XXVII. Beitrag zur Kenntnis der Amphipoden. Arten der Genera Echinogammarus Stebb. und Chaetogammarus Mart. an der jugoslawischer Adriaküste. - Glasnik Republičkog zavoda za zaštitu prirode i Prirodnjačke zbirke u Titogradu, 2: 59-84, 7 pls.

KARAMAN, G. 1986. New data on the Genus Niphargus Schiödte (Fam. Niphargidae) in Italy and adjacent regions (Contribution to the Knowledge of the Amphipoda 138). - Bollettino del Museo Civico di Storia Naturale, Verona, 12: 209-228, figs. I-VIII. (1985).

KARAMAN, G. \& RUFFO, S. 1986. Amphipoda: Niphargus-Group (Niphargidae sensu Bousfield, 1982), in: Botosaneanu, L. (edit.): Stygofauna Mundi, A Faunistic, Distributional and Ecological Synthesis of the World Fauna inhabiting Subterranean Warers (including the Marine Interstitial), Leiden, E. J. Brill/ Dr. W. Backhuys, pp. 514-534.

KARAMAN, G. 1993. Crustacea Amphipoda di acqua dolce. - Fauna d'Italia, vol. XXXI: 1-337, pls. 154. - Edizione Calderini Bologna, Italia.

KARAMAN, G. 2012. Further investigations of the subterranean genus Niphargus Schiödte, 1849 (fam. Niphargidae) in Serbia. (Contribution to the knowledge of the Amphipoda 264).- Agriculture and Forestry, Podgorica, 58 (2): 45-64, 7 figs.

KARAMAN, S. 1952. Podrod Stygoniphargus u Sloveniji i Hrvatskoj. [Das Subgenus Stygoniphargus in Slovenien und Kroatien].- Prirodoslovna istraživanja, Odjel za prirodne i medicinske nauke, Jugoslavenska Akademija znanosti i umjetnosti Zagreb, 25: 3-38, figs. 1-62.

KARAMAN, S. 1954. Die Niphargiden des slovenischen Karstes, Istriens sowie des benachb. Italiens.- Acta, Musei Macedonici Sceintiarum Naturalium, Skopje, 2 (8): 159-180, figs. 1-48. 
RUFFO, S. \& STOCH, F. 2005. Crustacea Malacostraca Amphipoda. In: RUFFO, S. \& STOCH, F. (eds.), Checklist e distribuzione della fauna italiana. 10.000 specie terrestri e delle acque interne. Memorie del Museo civico di Storia naturale di Verona, (II Serie), Sezione Scienze della Vita, 16: 109-111.

STOCH, F. 1993. Indagini faunistiche sui crostacei delle acque sotterranee della Val Torre (Italia nordorientale).- Gortania, Atti del Museo Friul. St. Nat., Udine, 14: 167-183.

STOCH, F. 1996. La fauna delle acque carsiche sotterranee delle Valli del Torre e del massiccio dei Monti La Bernadia.- Memorie dell'Istituto Italiano di Speleologia, (s. II) 8: 81-88.

STOCH, F. 1997. La fauna delle acque carsiche sotterranee delle Valli del Natisone.- Memorie dell Istituto Italiano di Speleologia, Serie 2, 9: 89-100.

STOCH, F. 1998. Revision of the Niphargus stygius- group in Venetia and Trentino (Northeastern Italy), with description of three new species (Crustacea, Amphipoda, Niphargidae), Bolletino Museo Civico di Storia naturale Verona 22: 229-274.

STOCH, F. 2008. La fauna cavernicola delle Prealpi Giulie settentrionali.- Il fenomeno carsico delle Prealpi Giulie Settentrionali - Memorie del Istituto Italiano di Speleologia, (s. II), XX: 97-121. 